\title{
Editorial
}

\section{Alketa Peci}

Fundação Getulio Vargas / Escola Brasileira de Administração Pública e de Empresas

Rio de Janeiro / RJ — Brazil

This year of 2017 is remarkable for RAP for two reasons: we celebrate its $50^{\text {th }}$ Anniversary and RAP is now a bilingual journal - Portuguese and English - published exclusively online. From this moment, RAP is not just RAP - Revista de Administração Pública, but also RAP - Brazilian Journal of Public Administration. This change meets the journal's goal of consolidating its position as an academic journal of the Brazilian public administration that seeks to expand its academic contribution beyond national boundaries.

Above all, the changes to the journal aim at constantly improving the quality of the content of published contributions, providing a platform for articles that substantially reinforce transversal themes in public administration, in national and international contexts.

However, the quest for quality is not something trivial. The particularity of the articles presented in each of RAP's issues depends on collective effort from a sometimes "invisible" community of reviewers, assistant editors, authors and readers that systematically collaborate to the journal. Quality also depends on a cultural change for all those involved, respecting the blind-review process, providing detailed and constructive reviews focused on developing the potential of a submitted manuscript, as well as responding to the reviewers with substantial changes in the paper, avoiding the 'make believe': all efforts aimed at obtaining a more robust final product that contributes to advance the knowledge on public administration.

From the first editorials under my responsibility, I have emphasized that my main commitments were with the quality of the published articles and with the encouragement to a continuing process of cultural change, in order to promote such quality. Considering that Brazil now has more than 100 academic journals - a number that is proof of the unbridled search for publishing papers - we need to focus more on quality than on quantity.

In this first editorial of 2017, I would like to highlight the work and dedication of RAP's reviewers. With the help of Eliane Barbosa da Conceição (Editorial Support), I carefully evaluated all the reviews received during 2016, verifying the depth of reviewers' comments and suggestions, the constructive tone of reviews, and the follow-up after receiving the revised papers. I chose to disclose the top 10 reviewers - senior and junior researchers - as a way to highlight the diversity of the scholars who contribute to the journal.

It is with my deep appreciation that we publish here the name of these collaborators, distinguished for the quantity and quality of the reviews they processed, which supported RAP's editorial decisions. 
Anelise Graciele Rambo

Universidade Federal do Rio Grande do Sul (UFRGS)

Universidade Federal da Fronteira Sul (UFFS)

Catarina Segatto

Fundação Getulio Vargas/Eaesp

Ciro Campos Christo Fernandes

Escola Nacional de Administração Pública (Enap)

Diego Araujo Reis

Universidade Federal de Sergipe (UFS)

Hugo Consciência Silvestre

Universidade da Integração Internacional da Lusofonia Afro-Brasileira (Unilab)

José Paulo Cosenza

Universidade Federal Fluminense (UFF)

Juliana Arcoverde Mansur Kopp

Fundação Getulio Vargas/Ebape

Liliane Magalhães Girardin Pimentel Furtado

Fundação Getulio Vargas/Ebape

Renata Mirandola Bichir

Universidade de São Paulo (USP)

Tomas de Aquino Guimarães

Universidade de Brasília (UnB)

Now we are introducing the first issue of 2017, it is important to stress that the field of public administration still needs research that consolidates and deepens the theoretical and practical debates that distinguish public administration as a specific field of knowledge. One of the persistent themes in the field is Bureaucracy, a theme that permeates the contributions gathered in the first bilingual issue of RAP online. The present issue brings together a number of contributions that discuss the multifaceted perspectives of the study of bureaucracy(ies): its role at the various administrative levels; its (differentiated) processes of professionalization; the specificities of street bureaucracy in public policies' implementation processes; and broader discussions about the relationship of bureaucracy with the capacity of the State to build and implement specific policies.

The persistence of the theme of bureaucracy in public administration studies is expected, considering that this is part of the executive branch of the government, defined as a government in action (Wilson, 2002). Yet, where does bureaucracy as a "fourth power" find legitimacy? In fact, nonelected 
public administrators - bureaucrats - legislate, making rules that sometimes have more enforcement power than the laws themselves; they implement rules (execute) and adjudicate issues related to their application and execution (role of the Judiciary), collapsing, in practice, the ideal of the separation of powers (Rosenbloom, 1983). Efficiency, neutrality, universalization, and democratization are some of the values that support its legitimacy, but have been historically disputable, as several articles in this issue implicitly or explicitly debate.

I wish you a good reading!

\author{
Alketa Peci \\ Editor-in-chief
}

\title{
REFERENCES
}

ROSENBLOOM, D. Public administrative theory and the separation of powers. Public Administration Review, v. 43. n. 3, p. 219-227, 1983.

WILSON, Wodrow. The study of public administration. In: SHAFRITZ, Jay M.; HYDE, Albert C.; PARKES, Sandra J. Classics of public administration. 5. ed. Belmont: Thomson-Wadsworth, 2002. (Original Source: Political Science Quarterly, v. 2, jun. 1887.)

\section{Alketa Peci}

$\mathrm{PhD}$ in administration and professor of Brazilian School of Public and Business Administration of Getulio Vargas Foundation. Editor-in-chief of Brazilian Journal of Public Administration - RAP. E-mail: alketa@fgv.br. 